\title{
Impact of the Foreign Direct Investment on Economic growth in the Republic of Benin
}

\author{
http://doi.org/10.21272/fmir.3(2). 69-78.2019
}

\section{Dossou Toyo Amegnonna Marcel}

$\mathrm{PhD}$ candidate in School of Economics in Southwestern University of Finance and Economics, China

\begin{abstract}
This paper empirically examines the impact of foreign direct investment (FDI) on economic growth in the Republic of Benin. Using the Error Correction Model (ECM), annual time series data the period of 1970-2017 were analyzed employing an ECM technique to determine the short and long-run impact of FDI on economic growth in the Republic of Benin. Granger causality methodology was used to analyze and establish the nature of the relationship (if any) between FDI and economic growth in the Republic of Benin. Our empirical analysis reveals that Foreign Direct Investment (FDI) has both immediate and time lag effect on the Republic of Benin economy in the short run. And FDI has a significant but negative effect on the Republic of Benin economy in the long run during the period under review. This was further confirmed by the causality test which shows that FDI granger causes RGDP and not the other way. Thus, FDI has a significant positive effect on the growth as well as the development of the Nigerian economy only in the long run during the period under review. I therefore conclude and recommend that government should ensure stable macroeconomic policies as a stabilization tool to propel the attraction of more FDI into the Republic of Benin and dependency on foreign direct investment should remain limited.
\end{abstract}

Keywords: FDI, economic growth, ECM, Granger causality,

JEL Classification: C22; E22; F14.

(C) The Authors, 2019. This article is published with open access at Sumy State University.

Cite as: Marcel, D. T. Am. (2019). Impact of the Foreign Direct Investment on Economic growth on the Republic of Benin. Financial Markets, Institutions and Risks, 3(2), 69-78. http://doi.org/10.21272/fmir.3(2). $\underline{69-78.2019}$

\section{Introduction}

Foreign direct investment (FDI) is viewed as a major stimulus to economic growth in developing countries. Its ability to deal with two (2) major obstacles, namely shortages of financial resources, technology and skills has made it the center of attention for policy-makers in low-income countries in particular. There are several benefits of foreign direct investment to a developing country. Firstly, FDI is a transfer of capital from the rich countries to the poor countries and capital is vital to economic growth. Secondly, FDI from the developed countries to the developing countries involves a transfer of technology, skills, and know-how. Thirdly, FDI may contribute to employment creation. Fourthly, FDI helps developing countries to access world markets. Fifthly, FDI flows tend to be less volatile than other types of foreign capital, such as foreign debt. (Todaro, 1994) Trusted that that FDI encourages the inflow of technology and skills and fills the gap between domestically available supplies of savings, foreign exchange, and government revenue.

In 2017, net FDI inflows (\% of GDP) for Benin were $2 \%$. Though Benin net FDI inflows (\% of GDP) fluctuated substantially in recent years, it tended to increase through $1998-2017$ period ending at $2 \%$ in 2017. This period coincided with the Republic of Benin becoming a part of Economic Community of West African States (ECOWAS), West African Economic and Monetary Union (WAEMU) and the World Trade Organization (WTO) with a view to facilitate an increase in FDI inflows and promote economic growth and development. According to the 2014 Investment Climate Statement released by the U.S. Department of State, the Government of Benin, with support from the World Bank, the African Development Bank, and the UNDP organized an investment forum in Paris to promote FDI projects. The objective was to assemble both governmental and non-governmental organizations to create investment opportunities in the Republic of Benin.

According to the report, the Government of Benin has singled out infrastructure spending, especially on ports and railways, energy, healthcare and also agriculture for economic development. The key role infrastructure 
Financial Markets, Institutions and Risks, Volume 3, Issue 2, 2019 ISSN (online) - 2521-1242 ISSN (print) - 2521-1250

is broadly admitted to being vital for economic achievement, and infrastructure assets are encouraged as leading to economic growth, either at the domestic or national level. In every nation, government seeks to protect the consumer's interest and maintaining a modern regulatory system. According (Shailender Singh , et al., 2017) study revealed that improving infrastructure will boost economic growth and attract more foreign direct investment and will also improve the welfare of the society.

Regarding (WTO, 1996) analysis the distinction of FDI occurs when an investor based in one country (the home country) acquires an asset in another country (the host country) with the intent to manage that asset. To manage this dimension is what distinguishes FDI from portfolio investment in foreign stocks, bonds, and other financial instruments". Moreover, FDI involves the transfer of much more than capital alone. Technological expertise, marketing, and management skills and other firm-specific resources are transferred to the host country as well. Every country has its own way of defining whether a given investment should be classified as FDI or foreign portfolio investment (FPI). The central objective of this paper, therefore, is to examine the trends in FDI inflows as it affects economic growth of third world countries with specific reference to the Republic of Benin.

The purpose of this paper is to show the contribution of FDI to economic growth in Republic of Benin so as to know whether the call for more FDI is truly justified. The relationship between FDI and economic growth in the country is discussed and the contribution of FDI to growth will be uncovered. To achieve these, scholarly opinions and suggestions will be discussed and empirical analysis on FDI will be carried out. What has been the contribution of the FDI inflow to the economic growth? Has the contribution been positive or not? Is the contribution increasing over time? This study attempts to answer these questions and more.

The rest of the paper is organized as follows. Section 2 will present prior related studies on foreign direct investment and economic growth relationship. Section 3 will discuss the data and methodology. Section 4 will present empirical findings and discussion. Finally, section 5 will summarize and conclude the paper.

\section{Literature review}

For the last two (2) decades, many countries have been making earnest effort to promote their economies as the place for foreign direct investment (FDI, hereafter). The foreign direct investment represents a crucial source of foreign exchange and technological transfer, especially to a developing economy like the Republic of Benin. Decades after World War II, many developing countries were not enthusiastic about foreign investment. Even some economically successful countries, such as South Korea, had been reluctant to accept foreign direct investment until the recent financial crisis (although it had emphasized exports). Times have changed and most economists have now recognized that foreign investment is beneficial to less developed countries. There are several benefits of foreign direct investment to a developing country (see Perkins et al., 2001, for a detailed discussion) highlight several benefits of FDI that could promote economic growth, for example, knowledge spillover of technology transfers, introduction of new processes to domestic market, learning-byobserving, training of labor force and managerial skills, among others.

Previous studies on the Foreign Direct Investment (FDI) and economic growth in the Republic of Benin and other countries provided inconclusive evidence. According to the issue the globalization the FDI is crucial for every country to promote the economy through the labor, transfer the skill, the technology. The previous study shows that the impact of the FDI on economic growth can be positive, negative or significant; it is depending on the economic through the infrastructure (because of the effort the government according the public spending). For instance, (Marcel, 2019) investigated the determinant of economic growth in Benin. The work covered the period 1970-2017 using an annual data from the World Bank indicators. A growth model via OLS method to determine the indicators which impact the economic growth of Benin. The result of OLS techniques indicated that FDI has a positive and significant impact on Benin economic growth for the period under study. And the author recommended to the government to invest more in the infrastructure to attract more foreign investors. (Adeleke Kunle M \& Olowe S.O, 2014) analyzed the impact of FDI on Nigeria economic growth over the period of 1999-2013. Using secondary data sourced from various publications of the central bank of Nigeria and statistical Bulletin, Annual Report and statement of Account. The result revealed that the foreign direct investment has direct impact of the Nigeria Economic growth and significant at 5\%. They concluded that foreign direct investment is an engine of economic growth. (Aliyu, n.d.) recognized in her study that the foreign direct investment is key ingredient for successful growth in the developing countries and her study found that the foreign direct investment impact positively, strongly and significantly the economic growth of 
Nigeria. According to her recommendation the country must improve on it's the foreign direct investment as this will go long way in improving on her economic growth. (Dr. Uwubanmwen, Ahmed E \& Mr. Ogiemudia Omorose A., March 2016)empirically examined the impact of foreign direct investment on economic growth in Nigeria. Using the Error correction Model annual secondary time series data covering the period 1979 to 2013 were analyzed employing ECM technique. The result revealed that in the short run the FDI has a significant positive effect on the growth. And they recommended that the government should ensure stable macroeconomic policies as a stabilization way to propel the attraction of more FDI into Nigeria and dependency on foreign direct investment should remain limited. (Johansein Rutaihwa \& Aneth Simwela, October 2012) examined the role of FDI in the Mining sector to Tanzania's Export capacity during 1989-2009. Using OLS to analyze this purpose the result revealed that the relationship between Tanzania export and FDI in mining was statically significant. (Alhassan Musah, et al., 2018) studied the impact of foreign direct investment on economic growth in Ghana to include the impact of FDI on the performance of commercial banks in Ghana. The study was used secondary data of FDI and macroeconomic variables for the World Bank data over 10 years period. The study revealed that FDI is positively associated and statistically significant with economic growth both in the short run and long run. (Abdul Khaliq \& Ilan Noy , 2007) investigated the impact of foreign direct investment on economic growth using detailed sectoral data for FDI inflows to Indonesia over the period. The result revealed that the impact of FDI on economic growth in positively significant. (Moudatsou, 2003) investigated the impact of foreign direct investment in European Union countries, when controlling for other growth determinants. Using data over the period 1980-1996. The result revealed that FDI has a positive effect on the growth rate of EU economies both directly and indirectly (through trade reinforcement).

Moreover (Nor Hakimah Haji Mohd. Nor, et al., 2013) examined the role of the banking development quality in the FDI-growth nexus over the period 1998-2009. The result for developed countries shows that the FDI is negatively related to economic growth. (Adewumi, 2006) examined the contribution of foreign direct investment to economic in Africa and regression analysis. Using data from the entire continent and data for eleven countries within the continent were used for the empirical analysis. The data covered the period from 1970 to 2003. The result showed that the contribution of FDI to growth is positive but not significant.

In on other hands (E. Borensztein, et al., 1998) test the effect of the foreign direct investment (FDI) on economic growth in cross-country regression framework. Using data on FDI flows from industrial countries to 69 developing countries over two decades. Their result found that FDI is a crucial vehicle for transfer of technology, contributing relatively more to growth than domestic investment.

\section{Methodology and Data}

\subsection{Variables Description}

The model consists of five variables, RGDP per capita (RGDP), foreign direct investment per Capita (FDI), Exchange Rate (EXR) and Trade Openness as a percentage of GDP (TOP). The subscript represents respective variables at time t. amongst these variables, RGDP is specified as the dependent variable, FDI and BM is the core explanatory variable and the remaining five as the control explanatory variables because they are a significant determinant of economic growth.

3.1.1 Real GDP Growth Rate. Our dependent variable in this case is LRGDP for which was used Real GDP per Capita. We have found in the literature (Roubini, N \& Sala-i-Martin, X, 1992), and (King, R.G \& Levine, $\mathrm{R}$, 1993)that RGDP per Capita has been used as a proxy for economic growth. Another reason for using GDP per capita is to incorporate the population effect.

\subsubsection{Foreign Direct Investment}

Foreign Direct Investment is an essential and significant forecaster of the Economic Growth (Kowalski, 2000). FDI is a stimulator for economic growth in under-developed countries (Tsai, 1994). (Akram, S, et al., 2011) has established a negative association of FDI with GDP growth by taking panel data of crosses countries. The proxy used for FDI is the annual FDI data in US\$. Data for this variable is taken from the World Bank indicators.

\subsubsection{Exchange Rate}

Output growth could mainly be explained by own shocks but was negatively affected by increases in exchange rate depreciation as well (Rodriguez, G. H \& Guillermo, G. D, 1995)and (Rogers, J. H. \& Ping Wang, 1995) obtained similar results for Mexico. The surrogate that was used for this variable is Exchange rate and that data will be collected from World Bank indicators. It is expected to have a positive sign. The expected sign 
Financial Markets, Institutions and Risks, Volume 3, Issue 2, 2019

ISSN (online) - 2521-1242 ISSN (print) - 2521-1250

for foreign direct investment is positive.

\subsubsection{Trade Openness}

Trade has been taken as one of the key variables affecting economic growth. Trade openness has been widely used with a proxy of trade to GDP ratio in the literature, e.g. (Beck, R. L \& Loayza, N, 2000).I have used Trade as a percentage of GDP as a proxy for trade variable and expect this variable to have a negative sign because of high imports as compared to exports in Nigeria. The data will be taken from World Bank indicators.

\subsubsection{Broad money}

Broad money is key factor for the investor to invest in other country as developed by (N. M.Gatawa, et al., 2017) and the result revealed that broad money impact the economic growth positively.

\subsection{Preliminary Test and Estimation Procedure}

The econometric analysis we used for this study was based on co-integration econometric techniques. Prior to analysis involving co-integration, one needs to examine the stationarity for each individual time series variable since the assumptions for the classical regression model require that both variables be stationary and that errors have a zero mean and finite variance (Engle \& Granger, 1987)The unit root test was evaluated using the Augmented Dickey-Fuller (ADF) and Philip Peron (PP) test which can be determined as:

$$
\Delta Y_{t}=\alpha+\delta Y_{t-1}+\gamma \sum_{i=1}^{m} \Delta Y_{t-1}+\varepsilon_{t}
$$

Where trepresents the drift, $\mathbf{t}$ represents deterministic trend and $\mathbf{m}$ is a lag length large enough to ensure that $\varepsilon_{t}$ is a white noise process.

While Philip Peron test is based on the following equation:

$$
\Delta Y_{t}=\beta_{0} D_{t}+\pi Y_{t-1}+\mu t
$$

When the data set was stationary and integrated of the same order. Thereafter, the Engle and Granger (1987) two-stage co-integration technique was used to check the existence of the long-run relationship between changes the dependent variable and all the explanatory variables. This is to ensure that the variables converge in the long run, as a variable that does not converge may be detrimental to policymaking. This method was carried out using econometric software (E-view8.0) version. Finally, the test for significance of all parameters was done using t statistics; we must acknowledge here that some diagnostic test was carried out to check the authentication of our analysis.

\subsection{Model Specification}

The starting point of our empirical model is the augmented Cobb-Douglas production function framework, a modified form of equation (3) above, with FDI incorporated as one of the factor inputs and Debt, Inflation rate, Trade Openness, Exchange rate, Gross domestic investment and Growth rate of capital stock as ancillary variables. Substituting these variables into equation (3) above we have

$\triangle R G D P_{t}=f(L F D I, L T O P, L E R, L B M)$

The proposed long-run equation in this study is specified as follow:

$$
\triangle R G D P_{t}=\alpha_{0}+\beta_{1} L F D I_{t}+\beta_{2} L T O P_{t}+\beta_{2} L E R_{t} \beta_{4} L B M_{t}+\pi_{t}
$$

Hence the error correction model used in this study as short run equation is specified as:

$$
\begin{aligned}
& \Delta \mathrm{RGDP}_{\mathrm{t}}=\alpha_{0}+\beta_{1} \sum_{\mathrm{t}=1}^{\mathrm{n}} \Delta \mathrm{RGDP}_{\mathrm{t}-1}+\beta_{2} \sum_{\mathrm{t}-1}^{\mathrm{n}} \Delta \mathrm{LFDI}_{\mathrm{t}-1}+\beta_{3} \sum_{\mathrm{t}-1}^{\mathrm{n}} \Delta \mathrm{LTOP}_{\mathrm{t}-1}+\beta_{4} \sum_{\mathrm{t}-1}^{\mathrm{n}} \Delta \mathrm{LBM}_{\mathrm{t}}+\partial 1 \mathrm{Ecm}(-1)+ \\
& +5
\end{aligned}
$$

Where

LRGDP $=$ Log GDP per capita

LFDI $=$ Log Foreign Direct Investment (US dollars)

LTOP $=$ Log Trade Openness (Volume of trade / GDP)

$\mathrm{EXR}=$ Exchange Rate

LBM $=$ Log Broad Money (US dollars) 
$\alpha 0=$ Constant $($ Intercept $)$

$$
\beta_{1}, \beta_{2}, \beta_{3} \text { and } \beta_{4}=\text { coefficients }
$$

$\operatorname{Ecm}(-1)=$ error correction term

$\mathrm{t}=$ respective variables at time $\mathrm{t}$

$\beta_{i}=$ captures the short-run.

$\partial_{\mathbf{1}}=$ captures the long-run impact.

A priori expectations as derived from empirical literature are expressed as: $\alpha 0>0 ; \beta 3>0$ while $\beta 1, \beta 2, \beta 4,<0$

On a final analysis, Engle and Granger causality test was used to ascertain the direction of causality between the variables. That is (if any) between FDI and its contributory variables on one side and economic development on the other side. The Engle and Granger causality test is specified as:

$$
\Delta Y_{t}=\beta_{0}+\sum_{t=1}^{n} \beta 1(1-L) \Delta Y_{t-1}+\sum_{t-1}^{n} \beta 2(1-L) \Delta X_{t-1}+\partial 1 E c m(-1)+\varepsilon_{t}
$$

Where $\Delta \mathrm{Yt}$ are the dependent variable and $\mathrm{Xt}-1$ is the explanatory variables. The direction of the causality is determined by the F-statistic. While the $t$ statistic on the coefficient of the lagged error-correction term represents the long-run causal relationship, the $\mathrm{F}$ statistic on the explanatory variables represents the short-run causal effect (Odhiambo, 2010a).

\section{Empirical Results}

Table 1. Summary of regression result

\begin{tabular}{|l|l|l|l|}
\hline \multicolumn{1}{|c|}{ Variables } & \multicolumn{1}{c|}{ Coefficient } & \multicolumn{1}{c|}{ T-value } & \multicolumn{1}{c|}{ Sign } \\
\hline LFDI & -0.166485 & -6221716 & 0.0000 \\
\hline LBM & 0.037703 & 1.114160 & 0.2714 \\
\hline LER & -0.009943 & -0.628058 & 0.5333 \\
\hline LTOP & 1.030044 & 10.78356 & 0.0000 \\
\hline$R^{2}$ & & & 0.926049 \\
\hline AjustedR ${ }^{2}$ & & & 0.919170 \\
\hline F-statistics & & & 134.6162 \\
\hline Durbin-Watson stat & & & 0.680300 \\
\hline
\end{tabular}

Source: Extracted from E-view 8.0 Output (Author's Computation, 2019).

Cumulatively, the $\mathrm{R}^{2}$ which is the coefficient of determination indicates that $92.6 \%$ of the changes in the gross domestic product of the Republic of Benin are caused by its independent variables within the study period. In addition, the adjusted $\mathrm{R}^{2}$ further buttress the $\mathrm{R}^{2}$, meaning that after adjusting for error, the independent variables can still explain the dependent variable which is gross domestic product by $92.6 \%$.

The F-statistics value of 134.6162 indicates that the model of the study is well fitted; this implies that the variable used in the study is well selected, combined and used. This result can further be substantiated by its significance value implying that the inferences to be drawn from the result will not be due to mere chance as there is $99 \%$ percent assurance. The Durbin Watson value which is far and above $50 \%$ indicates that serial correlation or autocorrelation is not a problem.

The foreign direct investment has a coefficient value of -0.166485 and t-value of -6221716 which is significant at $1 \%$. This shows that foreign direct investment is strongly, negatively and significantly influencing the gross domestic product of the Republic of Benin within the study period. This implies that when there is one dollar (1.00) increase in the amount spent on foreign direct investment, the gross domestic product of the Republic of Benin will decrease by dollars 0.166485 . This finding is in line with those who found that FDI is negatively related to economic growth. It also contradicts the studies of (Carkovic, M \& Levine, R, 2002); (Beugelsdijk, S., et al., 2008) ; (Herzer, D, et al., 2008) who found no significant relationship between FDI and economic growth.

The broad money has a coefficient value of 0.037703 and t-value of 1.114160 which is not significant at $1 \%$. The exchange rate has a coefficient value of -0.009943 and $t$-value of -0.628058 which is not significant at $1 \%$. The trade openness has a coefficient value of 1.030044 and t-value of 10.78356 which is significant at 
Financial Markets, Institutions and Risks, Volume 3, Issue 2, 2019

ISSN (online) - 2521-1242 ISSN (print) - 2521-1250

$1 \%$. This shows that trade openness is strongly, positively and significantly influencing the gross domestic product of Republic of Benin within the study period. This implies that when there is one dollar (1.00) increase in the amount spent on foreign direct investment, the gross domestic product of Republic of Benin will increase by dollars 1.030044

Table 2. Descriptive Statistics

\begin{tabular}{|l|c|c|c|c|c|}
\hline & LOGRGDP & LOGTOP & LOGFDI & LOGER & LOGBM \\
\hline Mean & 6.508766 & 4.120129 & 3.012382 & -5.935080 & 3.159801 \\
\hline Median & 6.463285 & 4.145290 & 3.238809 & -6.105754 & 3.144567 \\
\hline Maximum & 6.756877 & 4.461737 & 3.891988 & -4.123979 & 3.750478 \\
\hline Minimum & 6.301049 & 3.679786 & 0.697252 & -6.600271 & 2.386420 \\
\hline Std. Dev. & 0.133982 & 0.229765 & 0.784141 & 0.462943 & 0.313883 \\
\hline Skewness & 0.341228 & -0.276007 & -1.122099 & 1.228663 & -0.182569 \\
\hline Kurtosis & 1.923385 & 1.904225 & 3.615475 & 5.826929 & 2.934183 \\
\hline Jarque-Bera & 3.249691 & 3.010882 & 10.83047 & 28.05997 & 0.275316 \\
\hline Probability & 0.196942 & 0.221919 & 0.004448 & 0.000001 & 0.871397 \\
\hline & & & & & \\
\hline Sum & 312.4208 & 197.7662 & 144.5943 & -284.8838 & 151.6704 \\
\hline Sum Sq. Dev. & 0.843709 & 2.481224 & 28.89924 & 10.07287 & 4.630546 \\
\hline & & & & & \\
\hline Observations & 48 & 48 & 48 & 48 & \\
\hline
\end{tabular}

Source: Extracted from E-view 8.0 Output (Author's Computation, 2019).

Table 2 reveals that the variables under consideration are found to be normally distributed. The ratio of mean to the median of each variable is approximately one (except for FDI and ER). The standard deviation of each variable is also low. The table also revealed a reasonable range of variation between maximum and minimum values. Kurtosis measures the peakedness or flatness of the distributions, the kurtosis statistics of (1.92) and (1.90), for LRGDP, LTOP, respectively, were wide apart and not close to three (3) as a benchmark for normal distribution. This implies that the series for these three variables do not possess flat distributions that are relative to normal. For LFDI and LER have (3.61) and (5.82) as kurtosis value respectively which is wide apart from the criterion value of three (3), this implies that the series of these variables have a peaked distribution. As only LBM has kurtosis value of 2.93 which is close to three (3) as bench mark, which confirms near normality. The Jarque-Bera test statistics and its corresponding probability values also accept the null hypothesis of a normal distribution of each variable.

\subsection{Stationarity Results}

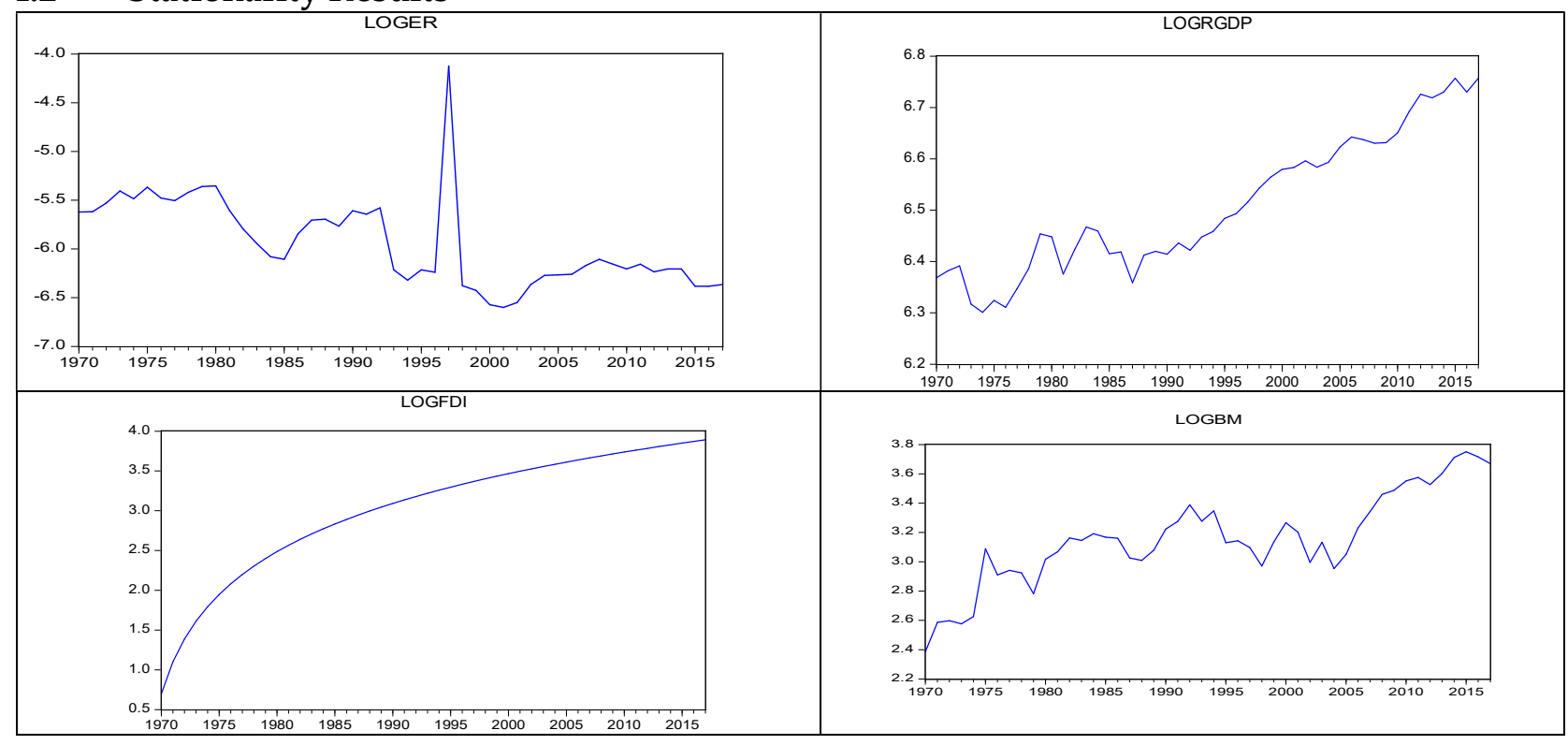




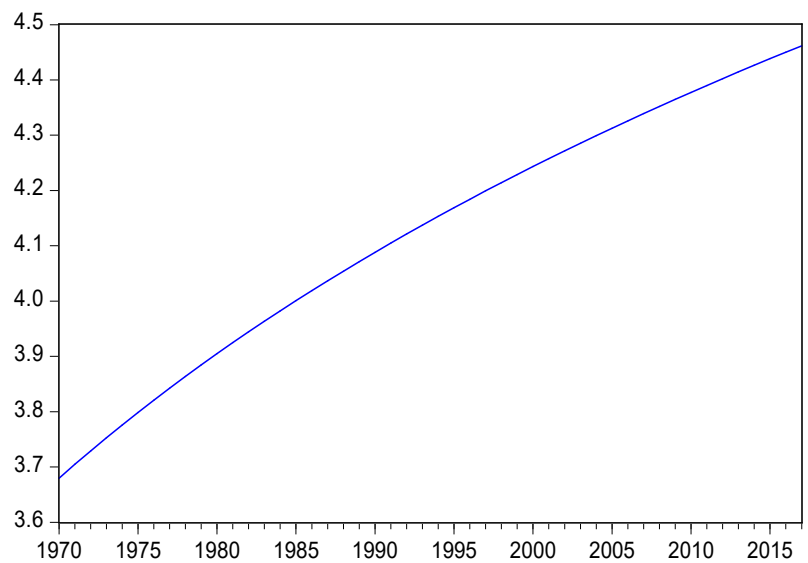

Figure. Line and symbol of stationary

Table 3. Unit root test result

\begin{tabular}{|c|c|c|c|c|c|c|c|}
\hline \multicolumn{3}{|c|}{ AugumentedDicky-Fuller Test } & \multicolumn{4}{c|}{ Phillip-Perron Test } \\
\hline Variable & Adf Stat & Order & Remark & Variable & Adf Stat & Order & Remark \\
\hline LRGDP & 2.925169 & $\mathrm{I}(0)$ & Non stationary & LRGDP & 0.536379 & $\mathrm{I}(0)$ & Non stationary \\
\hline & $6.765122^{*}$ & $\mathrm{I}(1)$ & Stationary & & $6.942691^{*}$ & $\mathrm{I}(1)$ & Stationary \\
\hline & $4.906839^{*}$ & $\mathrm{I}(2)$ & Stationary & & $32.01569^{*}$ & $(2)$ & Stationary \\
\hline LFDI & $5.944123^{*}$ & $\mathrm{I}(0)$ & Stationary & LFDI & $14.89850^{*}$ & $\mathrm{I}(0)$ & Stationary \\
& $12.32567^{*}$ & $\mathrm{I}(2)$ & Stationary & & $20.62733^{*}$ & $\mathrm{I}(1)$ & Stationary \\
\hline \multirow{2}{*}{ LER } & $4.897451^{*}$ & $\mathrm{I}(2)$ & Stationary & & $31.54967^{*}$ & $\mathrm{I}(2)$ & Stationary \\
& $5.902825^{*}$ & $\mathrm{I}(0)$ & Stationary & LER & $5.842855^{*}$ & $\mathrm{I}(0)$ & Stationary \\
& $10.51142^{*}$ & $\mathrm{I}(2)$ & Stationary & & $35.17773^{*}$ & $\mathrm{I}(1)$ & Stationary \\
\hline LBM & $9.088952^{*}$ & $\mathrm{I}(2)$ & Stationary & & $78.11088^{*}$ & $\mathrm{I}(2)$ & Stationary \\
& 3.079692 & $\mathrm{I}(0)$ & Non Stationary & LBM & 3.063658 & $\mathrm{I}(0)$ & Non Stationary \\
& $7.920432^{*}$ & $\mathrm{I}(1)$ & Stationary & & $7.979297^{*}$ & $\mathrm{I}(1)$ & Stationary \\
\hline LTOP & $12.46987^{*}$ & $\mathrm{I}(2)$ & Stationary & & $26.128665^{*}$ & $\mathrm{I}(2)$ & Stationary \\
\hline & & & & LTOP & $30.85179^{*}$ & $\mathrm{I}(0)$ & Stationary \\
\hline
\end{tabular}

NB: * represents significant at $1 \%$.

Source: Extracted from E-view 8.0 Output (Author's Computation, 2019).

All the variables under the ADF test are stationary except RGDP and LBM as shown in the Table 2. At level the calculated PP test statistics clearly reject the null hypothesis of unit root at $1 \%$ significance levels when compared with their corresponding critical values, hence the ADF and PP tests decisively confirm stationarity of each variable although at second and first differencing respectively, and indicate different order of integration i.e. I (1) and I (2) behavior.

\subsection{Co-integration Results}

Table 4. Engle and Granger Co-integration test

\begin{tabular}{|l|l|l|l|}
\hline Variables & Level & Mackinnon Critical values & Remark \\
\hline RESID(ECM) & 33.2144 & $3.841466^{*}$ & stationary \\
\hline *stationary at 1\% level of significance & \multicolumn{2}{|l}{} \\
\hline
\end{tabular}

Source: Extracted from E-view 8.0 Output (Author's Computation, 2019).

The (Engle \& Granger, 1987)two-stage co-integration techniques result in table 4 above, depicts that the residuals from the regression result are stationary at a $1 \%$ level of significance. This means that all the explanatory variables are co-integrated with Real Gross Domestic Products (RGDP) in the Republic of Benin over periods under consideration $(1970$ - 2017). In order words there exists a long-run stable relationship between the dependent and independent variables. This finding also reveals that any short-run deviation in their relationships would return to equilibrium in the long run. As a result, the error correction model is estimated.

Table 5. ECM Short run and Long run regression results 
ISSN (online) - 2521-1242 ISSN (print) - 2521-1250

\begin{tabular}{|c|c|c|c|c|c|c|}
\hline \multicolumn{7}{|c|}{$\begin{array}{l}\text { Short run dependent variable: LRGDP } \\
\text { Long run dependent variable: LRGDP }\end{array}$} \\
\hline Variable & $\begin{array}{l}\text { Ecm Short } \\
\text { Run } \\
\text { Coefficient } \\
\end{array}$ & T-Statistic & Prob. & $\begin{array}{l}\text { Long Run } \\
\text { Coefficient }\end{array}$ & T-Statistic & Prob. \\
\hline LBM & & & & 0.005274 & 1.175197 & 0.2413 \\
\hline LFDI & & & & 0.000564 & $18.15990^{*}$ & 0.0000 \\
\hline LER & & & & -0.000211 & -0.012597 & 0.9900 \\
\hline LTOP & & & & $-1.631 \mathrm{e}-06$ & $-49.28135^{*}$ & 0.0000 \\
\hline LFDI(-1) & -0100886 & -0284291 & 09697 & & & \\
\hline LFDI(-2) & -1.3759997 & -0.971629 & 0.3324 & & & \\
\hline LFDI $(-3)$ & 0.000237 & $22.677766^{*}$ & 0.0000 & & & \\
\hline LFDI(-4) & 0.734823 & 0.139278 & 0.8894 & & & \\
\hline LFDI $(-5)$ & 0.475625 & $48.49889 *$ & 0.0000 & & & \\
\hline $\operatorname{LBM}(-1)$ & -0.037951 & -1.011000 & 0.3133 & & & \\
\hline $\operatorname{LBM}(-2)$ & -0.173466 & -1.157945 & 0.2483 & & & \\
\hline $\operatorname{LBM}(-3)$ & $-9.35 e-07$ & -0.846097 & 0.3985 & & & \\
\hline $\operatorname{LBM}(-4)$ & 0.054326 & 0.097342 & 0.9226 & & & \\
\hline $\operatorname{LBM}(-5)$ & -0.000858 & -0.826747 & 0.4094 & & & \\
\hline LTOP(-1) & -0.131064 & -0.059418 & 0.9527 & & & \\
\hline LTOP(-2) & -0.886302 & -0.100686 & 0.9199 & & & \\
\hline $\operatorname{LTOP}(-3)$ & 0.969606 & 14934.98* & 0.0000 & & & \\
\hline $\operatorname{LTOP}(-4)$ & -9.321887 & -0.284254 & 0.7765 & & & \\
\hline LTOP(-5) & 2.301524 & $37.75606^{*}$ & 0.0000 & & & \\
\hline $\operatorname{LER}(-1)$ & -0.000368 & -0.037973 & 0.9697 & & & \\
\hline $\operatorname{LER}(-2)$ & -0.070153 & $-1.814567 * * *$ & 0.0711 & & & \\
\hline $\operatorname{LER}(-3)$ & $7.16 \mathrm{e}-08$ & 0.251152 & 0.8020 & & & \\
\hline $\operatorname{LER}(-4)$ & -0.446205 & $-3097970 * *$ & 0.0022 & & & \\
\hline $\operatorname{LER}(-5)$ & $6.66 \mathrm{e}-05$ & 0.248747 & 0.8038 & & & \\
\hline R-squared & 0.069650 & & & & & \\
\hline Adjusted R-squared & -0.073480 & & & & & \\
\hline Durbin-Watson Stat & 2.069769 & & & & & \\
\hline
\end{tabular}

Source: Extracted from E-view 8.0 Output (Author's Computation, 2019).

Table 5 above reports the error correction model (ECM) for changes in RGDP in the Republic of Benin from 1970 to 2017 using autoregressive regression techniques. Specifically, one, two three, four and five period lag of Foreign Direct Investment (FDI) had a mixed effect on the Republic of Benin economy (LRGDP). The three and five period lags of FDI variable had positive and significant relationship with the Republic of Benin LRGDP except one and two period lags of FDI which had negative insignificant relationship and four periods lag positive insignificant relationship, this means that FDI effect on Beninese economy has both immediate and time lag effect in the short run. While the long run coefficient result shows that FDI has a significant positive effect on the Republic of Benin economy during the period under consideration. Also, the One period lag of exchange rate (EXR-2) and (EXR-4) considered in the short run had a significant negative effect on the Republic of Benin economy growth (LRGDP), while the current year EXR has an insignificant positive effect on the Republic of Benin economy. In the long run, EXR had a positive but insignificant effect on the Republic of Benin economy growth.

The results, in general, revealed that the LRGDP growth experienced in the Republic of Benin was greatly determined by Foreign Direct Investment (FDI), Trade Openness and Exchange Rate in the short run. And positively and significantly related to FDI and negatively significant related to TOP in the long run. The results also point out in clear terms that only TOP and FDI contributed significantly to LRGDP growth both in short and long run during the period under review. The results in the short run show that FDI, TOP, ER variable lags had a mixed relationship with LRGDP in the short-run. The ECM and OLS long-run regression with Durbin Watson-statistic value of 2.069769 and 2.39 respectively show that there is no evidence to accept the presence of autocorrelation in the model. This means that the model is valid and can be used for policy recommendation without re-specification.

\subsection{Causality test}


Table 6. Pairwise Causality

\begin{tabular}{|c|c|c|c|}
\hline Null Hypothesis: & Obs & F-Statistic & Prob. \\
\hline LOGTOP does not Granger Cause LOGRGDP & 47 & $6.48607 * *$ & 0.0144 \\
\hline \multicolumn{2}{|l|}{ LOGRGDP does not Granger Cause LOGTOP } & 56.1565 & 2.E-09 \\
\hline LOGFDI does not Granger Cause LOGRGDP & 47 & $3.07761^{* * *}$ & 0.0863 \\
\hline \multicolumn{2}{|l|}{ LOGRGDP does not Granger Cause LOGFDI } & 59.8147 & 1.E-09 \\
\hline LOGER does not Granger Cause LOGRGDP & 47 & 0.00019 & 0.9889 \\
\hline \multicolumn{2}{|l|}{ LOGRGDP does not Granger Cause LOGER } & $13.6785^{*}$ & 0.0006 \\
\hline LOGFDI does not Granger Cause LOGTOP & 47 & 267.050 & 3.E-20 \\
\hline \multicolumn{2}{|l|}{ LOGTOP does not Granger Cause LOGFDI } & 328.224 & 5.E-22 \\
\hline LOGER does not Granger Cause LOGTOP & 47 & 0.10777 & 0.7442 \\
\hline \multicolumn{2}{|l|}{ LOGTOP does not Granger Cause LOGER } & $14.8857^{*}$ & 0.0004 \\
\hline LOGER does not Granger Cause LOGFDI & 47 & $5.77273 * *$ & 0.0206 \\
\hline \multicolumn{2}{|l|}{ LOGFDI does not Granger Cause LOGER } & $11.6939 *$ & 0.0014 \\
\hline
\end{tabular}

$*$, ** and $* * *$ represent $1 \%, 5 \%$ and $10 \%$ significant level respectively.

Source: Extracted from E-view 8.0 Output (Author's Computation, 2019).

The macroeconomic outlook of the variables used in the analysis may imply interrelationships among them. Hence, the Granger causality test which is part of our estimation technique in this study is used to provide the background for estimating dynamic relationships. The results in Table 6 above shows the Pairwise Granger causality test among the variables analyzed. The F-test is conducted on the null hypotheses in order to determine the direction of causality between each pair of variables, and the rejection of each of the null hypothesis is based on the significance of the F-value for the particular relationship.

Most importantly, the test result reveals clearly that in relation to FDI, the null hypothesis that LRGDP does not Granger cause LFDI is accepted, but the null hypothesis that LFDI does not granger cause LRGDP is rejected. This implies that FDI Granger causes LRGDP that is there is a positive and direct relationship between FDI and LRGDP. The more FDI we have in the Republic of Benin, the higher the level of economic growth and development. This means that FDI has contributed significantly to the growth of the Republic of Benin economy during the period under consideration. In addition, between trade openness and foreign direct investment, we find that the bidirectional that means trade openness can cause the FDI and also the FDI can cause the Trade openness. The null hypothesis that LRGDP does not granger cause LER is accepted, but the null hypothesis that LER does not granger cause LRGDP is rejected. This implies that LRGDP Granger causes LER that is there is a positive and direct relationship between LER and LRGDP.

\section{Finding and concluding remarks}

Our empirical analysis reveals that Foreign Direct Investment (FDI) has both immediate and time lag effect on the Republic of Benin economy in the short run. And FDI has a significant positives effect on the Republic of Benin economy in the long run during the period under review. This was further confirmed by the causality test which shows that FDI granger causes RGDP and not the other way. Thus, FDI has a significant but negative effect on the growth as well as the development of the Republic of Benin economy only in the short run during the period under review. I therefore conclude and recommend that government should ensure stable macroeconomic policies as a stabilization tool to propel the attraction of more FDI into the Republic of Benin. Also, policy consistencies, investment and political stability are also pertinent in attracting and retaining foreign direct investment. Finally, government should increase its expenditure in the area of infrastructural development as ways to accelerate the growth of the Republic of Benin economy. Thus, dependency on foreign direct investment should remain limited.

Acknowledgments: The study is not funded by any organization.

Author Contributions: Dossou T. A. Marcel obtained and analyzed the data using econometric techniques. The author discussed the results and wrote the paper.

Conflicts of Interest: The authors declare no conflict of interest.

\section{References}

1. Abdul Khaliq, Ilan Noy. (2007). Foreign Direct Investment and Economic Growth: Empirical Evidence from Sectoral Data in Indonesia. 
Financial Markets, Institutions and Risks, Volume 3, Issue 2, 2019

ISSN (online) - 2521-1242 ISSN (print) - 2521-1250

2. Adeleke Kunle M., Olowe S.O. (2014). Impact of Foreign Direct Investment on Nigeria Economic Growth. International Journal of Academic Research in Business and Social Sciences, 4(4), $234-242$.

3. Adewumi, S. (2006). The Impact of FDI on Growth in Developing Countries. s.1.:s.n.

4. Akram, S, et al. (2011). Empirical Analysis of Determinants of Economic Growth: Evidence from SAARC Countries. Journal of Economics and Behavioral Studies, 3(2), 115-121.

5. Alhassan Musah, Erasmus Dodzi Gakpetor, Solomon Nana Kwaku Kyei \& Evans Akomeah. (2018). Foreign Direct Investment (FDI), Economic Growth and Bank Performance in Ghana. International Journal of Finance and Accounting, 27(4), 97-107.

6. Aliyu, M. S., n.d. the impact of foreign direct investment (FDI) on economic growth in Nigeria.

7. Beck, R. L \& Loayza, N. (2000). Finance and the Sources of Growth. Journal of Financial Economics, 58, 261-300.

8. Beugelsdijk, S., Smeets, R \& Zwinkels, R. (2008). The impact of horizontal and vertical FDI on host's country economic growth.. International Business Review, 17, 452-472.

9. Carkovic, M \& Levine, R. (2002). Does foreign direct investment accelerate economic growth? Working Paper. University of Minnesota Department of Finance.

10. Dr. Uwubanmwen, Ahmed E \& Mr. Ogiemudia Omorose A. (March 2016). Foreign Direct Investment and Economic Growth: Evidence from Nigeria. International Journal of Business and Social Science, 7(3), 89103.

11. E. Borensztein, J. De Gregorio \& J-W. Lee. (1998). How does foreign direct investment affect economic growth? Journal of International Economics, 115-135.

12. Engle, R. \& Granger. (1987). Cointegration and Error-correction - Representation,Estimation and Testing. s.l.:C.J.W.

13. Herzer, D, Klasen, S. \& Nowak-Lehmann, D.F. (2008). In search of FDI-led growth in developing countries: the way forward.. Economic Modelling, 25, 793-810.

14. Johansein Rutaihwa \& Aneth Simwela. (October 2012). Econometric Analysis of FDI in the Mining Sector to Tanzania's Export Capacity. International Journal of Academic Research in Business and Social Sciences, 2(10), 174-194.

15. King, R.G \& Levine, R, 1993. Finance and Growth: Schumpter Might Be Right. Quarterly Journal of Economics, 108(3), 717-737.

16. Kowalski, E. (2000). Determinant of Economic Growth in East Asia, s.l.: Research Honors Project.

17. Marcel, D. T. A. (2019). the determinant of economic growth in benin: Evidence form Benin Times serie analysis 1970-2017. Financial Markets, Institutions and Risks, 3(1), 63-74.

18. Moudatsou, A. (2003). Foreign Direct Investment and Economic Growth in the European Union. Journal of Economic Integration, 18(4), 689-707.

19. N. M.Gatawa, Akinola Abdulgafar \& Muftau O. Olarinde. (2017). Impact of Money Supply and Inflation on Economic Growth in Nigeria (1973-2013). IOSR Journal of Economics and Finance (IOSR-JEF), 8(3), 2637.

20. Nor Hakimah Haji Mohd. Nor, Soo-Wah Low, Abu Hassan Shaari Md Nor \& Noor A. Ghazali. (2013). FDI and Economic Growth Does the Quality of Banking Development Matter?. Gadjah Mada International Journal of Business, 15(3), 287 - 303.

21. Odhiambo, N. (2010a). Are Banks And Stock Markets Positively Related? Empirical Evidence From South Africa. Journal of applied business research, 26(6), 17-26.

22. Rodriguez, G. H \& Guillermo, G. D. (1995). Fluctuations Macroeconomics en la Economia Peruana, s.l.: Working Paper. Lima: Banco Central de Reservadel Perú..

23. Rogers, J. H. \& Ping Wang, (1995). Output, Inflation and Stabilization in a Small Open Economy: Evidence from Mexico. Journal of Development Economics, 46(2), 271-293.

24. Roubini, N \& Sala-i-Martin, X. (1992). Financial Repression and Economic Growth. Journal of Development Economics, 39(1), 5-30.

25. Shailender Singh , G. S. Batra \& Gajendra Singh. (2017). the role of Infrastructure in National Economic Development: Evidence from Malaysia. International Journal of Economic Perspectives, 11(1), 630-637.

26. Todaro, M. (1994). Economic development New York and London:. 5th Edition ed. s.1.: Longman.

27. Tsai, L. (1994). Determinant of Foreign Direct Investment and its Impact on Economic Growth. Journal of Economic Development, 19(1), 137-163.

28. WTO. (1996). Trade and foreign direct investment. 